\title{
Meningkatkan Hasil Belajar PPKn Materi Aturan di Rumah dan di Sekolah dengan Metode Role Reversal Question pada Siswa Kelas III SDN Dondak Tahun Pelajaran 2017/2018
}

\author{
Lalu Wideta \\ Guru Kelas III SDN Dondak Kecamatan Pujut Kab. Lombok Tengah
}

\begin{abstract}
Abstrak. Peneltian ini menggunakan penelitian tindakan kelas yang dilaksanakan dalam dua siklus. Adapun tujuan penelitian ini adalah untuk mengetahui peningkatan hasil belajar siswa kelas III SDN Dondak Tahun Pelajaran 2017/2018 setelah menggunakan Metode role reversal question subjek penelitian ini adalah siswa kelas III SDN Dondak dengan jumlah siswa 23 siswa terdiri dari laki-laki 10 orang dan perempuan 13 orang. Teknik analisis data menggunakan data kuantitatif pengolahan hasil tes hasil tes dengan menggunkan rumus prosentase. Berdasarkan hasil penelitian tindakan kelas yang telah dilaksanakan dalam dua siklus. Jika dibandingkan dari siklus I sampai dengan siklus II terjadi peningkatan hasil belajar yang cukup signifikan dimana pada siklus I diperoleh nilai rata - rata sebesar 69 meningkat pada siklus II menjadi 80 terjadi peningkatan sebesar 11 poin kemudian jumlah siswa yang tuntas pada siklus I sebanyak 13 orang atau persentase ketuntasan sebesar $57 \%$ meningkat pada siklus II menjadi 21 orang siswa yang tuntas belajar atau persentase ketuntasan belajar dengan menggunakan metode role reversal question, sebesar $91 \%$ terjadi peningkatan sebesar 43 poin ,dan begitujuga dengan ketuntasan klasikal yang dipersyaratkan sebesar $\geq 80$ sudah tercapai maka dengan demikian penelitian ini dihentikan sampai pada siklus II. Dari hasil Penelitia ditarik kesimpulan bahwa penggunaan metode role reversal question, dapat meningkatkan hasil belajar siswa kelas III SDN Dondak Kecamatan Pujut Tahun Pelajaran 2017 / 2018.
\end{abstract}

\section{Kata kunci: Hasil Belajar, Metode Role Reversal Question}

\section{PENDAHULUAN}

Pendidikan merupakan pengalaman belajar yang berlangsung dalam lingkungan dan diperoleh sepanjang hidup. Pendidikan dilakukan oleh keluarga, masyarakat dan pemerintah. Hal ini sesuai dengan pengertian pendidikan menurut Redja Mudyaharjo (2012: 11) yaitu: "pendidikan dapat diartikan usaha sadar yang dilakukan oleh keluarga, masyarakat dan pemerintah melalui kegiatan bimbingan pengajaran atau latihan yang berlangsung di sekolah dan diluar sekolah sepanjang hayat, untuk mempersiapkan peserta didik agar dapat memainkan peranan dalam berbagai lingkungan hidup secara tepat di masa yang akan datang."

Pendidikan formal merupakan satuan pendidikan di Indonesia. Menurut UndangUndang Republik Indonesia Nomor 20 Tahun 2003 pasal 1 tentang Sistem Pendidikan Nasional, diartikan bahwa sebagai kelompok layanan pendidikan pada jalur formal, nonformal dan informal ada setiap jenjang dan jenis pendidikan. Pendidikan formal terdiri dari pendidikan dasar, pendidikan menengah dan pendidikan tinggi. Pendidikan dasar meliputi sekolah dasar (SD), madrasah ibtidaiyah (MI) dan sekolah dasar luar biasa (SDLB), serta sekolah menengah pertama (SMP), madrasah tsanawiyah (MTs) dan sekolah menengah pertama luar biasa (SMPLB). Pendidikan menengah meliputi sekolah menengah atas (SMA), madrasah aliyah (MA), sekolah menenggah kejuruan (SMK) dan sekolah menengah atas luar biasa (SMALB). Sedangkan pendidikan tinggi meliputi pendidikan formal setelah pendidikan menengah.

Menurut Undang-Undang Nomor 20 Tahun 2003 PPKn merupakan mata pelajaran diwajibkan untuk jenjang pendidikan dasar, menengah dan mata kuliah wajib untuk pendidikan tinggi. Pada jenjang sekolah dasar PPKn diajarkan kepada siswa 
yang berusia 7-12 tahun dimana menurut Piaget merupakan fase perkembangan "operasional konkret". Menurut Piaget (Desmita, 2009: 104) karakteristik anak usia sekolah dasar masuk berada pada tahap operasional konkret, dimana aktivitas mental yang difokuskan pada obyek dan peristiwa yang nyata. Pendapat sama di kemukakan oleh Sri Esti Wuryani Djiwandono (2006: 6) bahwa sebagian besar anak sekolah dasar yang berada dalam operasional konkret kurang mampu berfikir abstrak. Jika dilihat dari pemikiran dan karakteristik anak usia sekolah dasar, maka dalam pelaksanaan pembelajaran PPKn guru dapat merencanakan kegiatan yang mengandung unsur keterlibatan siswa secara langsung.

Kenyataannya dalam proses pembelajaran PPKn di kelas, siswa belum sepenuhnya terlibat secara langsung, seperti halnya yang terjadi pada kelas III SDN Dondak. Kegiatan pembelajaran masih di dominasi metode ceramah saat menerangkan materi pelajaran, siswa tidak sepenuhnya memperhatikan penjelasan guru, dikarenakan bosan dengan aktivitas mendengarkan, sehingga pembelajaran PPKn dirasa kurang menyenangkan bagi siswa.

Dalam mengikuti pembelajaran PPKn motivasi belajar rendah terlihat saat berlangsungnya kegiatan belajar terdapat beberapa siswa yang membuat gaduh. Peneliti berulang kali mengkondisikan siswa yang gaduh untuk diam dan memperhatikan pembelajaran, namun hal tersebut tidak dihiraukan. Selain membuat gaduh saat pembelajaran PPKn , terdapat beberapa siswa yang tidak mengerjakan tugas dengan sungguh- sungguh. Ketika selesai menjelaskan pembelajaran guru memberikan tugas kepada siswa untuk mengerjakan soal, namun banyak siswa yang mengerjakannya dengan asal-asalan, karena mereka tidak mau membaca buku untuk menjawab soal.

Keadaan tersebut menimbulkan pemerolehan hasil belajar yang belum maksimal. Rendahnya hasil belajar PPKn dapat dilihat dari hasil ulangan harian dari 23 siswa yang tuntas belajar hanya 5 orang atau persentase ketuntasan sebesar sebesar $23 \%$. dan siswa yang belum tuntas belajar sebanyak 18 orang atau persentase sebesar $78 \%$. Ketuntasan Belajar dilihat dari pencapaian KKM di SDN Dondak, Sementara KKM yang ditetapkan di SDN Dondak untuk mata pelajaran PPKn tahun pelajaran 2017/2018 yaitu 70. Melihat jumlah siswa yang masih banyak memperoleh nilai dibawah kriteria ketuntasan dan rata-rata nilai PPKn yang belum maksimal maka perlu dilakukan peningkatan hasil belajar PPKn .

Rendahnya hasil belajar tersebut karena metode yang digunakan masih menggunkan metode konvensional dan bersifat monoton monoton, media pembelajaran yang tidak menarik dan tidak sesuai dengan materi pelajaran serta banyaknya materi yang harus dihapal oleh siswa.

Untuk mengatasi hal tersebut maka siswa perlu dilibatkan dalam pembelajaran secara penuh yang disebut dengan pembelajaran aktif ( active learning) salah satu model yang ditawarkan adalah pembelajaran aktif dengan menekankan pada kegitan tanya jawab.

Menurut Silberman, Mel (2007: 143) ada berbagai tipe active learning yang menekankan pada kegiatan tanya jawab yaitu starts with a question, role reversal question dan planted question. Kegiatan tanya jawab dapat membantu siswa untuk memperoleh pengetahuan, keterampilan dan keaktifan dalam belajar.

Dalam penelitian ini, peneliti menawarkan penggunaan metode active learning yang menekankan pada kegiatan tanya jawab (role reversal question). Penerapan role reversal question yaitu dengan melakukan tanya jawab dengan bertukar peran. Dengan melakukan tanya jawab dapat memudahkan siswa untuk memahami materi, menjadikan siswa aktif, dan dapat meningkatkan hasil belajar.

Berdasarkan uraian di atas, peneliti terdorong untuk melakukan penelitian dengan judul "Meningkatkan Hasil Belajar PPKn Materi Aturan di Rumah dan di Sekolah dengan Metode Role Reversal Question pada Siswa Kelas III SDN Dondak Tahun Pelajaran 2017 /2018”. 


\section{Rumusan Masalah}

Berdasarkan latar belakang masalah di atas, maka rumusan masalah dalam penelitian ini adalah Bagaimanakah Meningkatkan Hasil Belajar PPKn Materi Aturan di Rumah dan di Sekolah dengan Metode Role Reversal Question pada Siswa Kelas III SDN Dondak Tahun Pelajaran $2017 / 2018$ ?

\section{Tujuan Penelitian}

Berdasarkan rumusan masalah di atas, maka tujuan penelitian ini adalah untuk Meningkatkan Hasil Belajar PPKn Materi Aturan di Rumah dan di Sekolah dengan Metode Role Reversal Question pada Siswa Kelas III SDN Dondak Tahun Pelajaran 2017 /2018".

\section{Manfaat Penelitian}

Adapun manfaat penelitian ini adalah : sebagai masukan dalam melakukan kegiatan pembelajaran di kelas, khususnya yang berhubungan langsung dengan peningkatan hasil belajar PPKn di SDN Dondak dengan menerapkan Metode role reversal question.

\section{KAJIAN PUSTAKA}

Pendidikan
$\begin{aligned} & \text { Kewarganegaraan } \\ & \text { Pendidikan }\end{aligned}$
$\begin{array}{lll}\text { Pancasila } \\ \text { dan }\end{array}$

Kewarganegaraan (PPKn) merupakan Mata pelajaran yang strategis dalam menyiapkan peserta didik sebagai generasi penerus dan sebagai anak bangsa yang baik. Melalui mata pelajaran PPKn telah direncanakan materimateri strategis, yang bersifat memberikan pembekalan agar peserta didik dapat menjadi anggota keluarga, warga sekolah dan sekaligus menjadi warga negara yang berperilaku baik, berbudi pekerti, bertanggung jawab, dengan memberikan penanaman nilai norma dan moral berdasarkan Pancasila

\section{Pendidikan Kewarganegaraan}

merupakan program pendidikan yang menekankan pada pembentukan warganegara agar dapat melaksanakan hak dan kewajiban. Sebagaimana disebutkan dalam Permendiknas Nomor 22 Tahun 2006 yaitu : Mata pelajaran PPKn merupakan mapel yang memfokuskan pada pembentukan warganegara yang memahami dan mampu melaksanakan hak-hak dan kewajibannya untuk menjadi warga Negara Indonesia yang cerdas, terampil, berkarakter yang diamanatkan oleh Pancasila dan UndangUndang 1945.

Menurut Zamroni (A. Ubaedillah \& Abdul Rozak, 2013: 15) Pendidikan Kewarganegaraan merupakan pendidikan demokrasi yang bertujuan untuk mempersiapkan masyarakat berfikir kritis dan bertindak melalui dengan menanamkan kesadaran bahwa demokrasi adalah bentuk kehidupan yang menjamin hak masyarakat. Sedangkan menurut Soemantri (A. Ubaedillah \& Abdul Rozak, 2013: 15) Pendidikan Kewarganegaraan (civic education) ditandai oleh kegiatan yang sudah diprogramkan oleh sekolah. Kegiatan ini meliputi kegiatan pembelajaran yang dapat menumbuhkan perilaku yang baik. Pendidikan Kewarganegaraan dilakukan dengan kegiatan yang menyangkut pengalaman yang dikaitkan dengan kehidupan nyata seperti kehidupan dalam keluarga dan masyarakat.

Berdasarkan beberapa pengertian di atas dapat disimpulkan bahwa PPKn merupakan mata pelajaran yang memfokuskan pada pembentukan warganegara. Dalam pembelajaran di sekolah, pembelajaran PPKn dapat dikaitkan dengan kehidupan sehari-hari. Dengan mengaitkan pembelajaran PPKn dengan kehidupan nytata dapat membentuk perilaku sesuai dengan nilai- nilai yang diharapkan. Tujuan Pendidikan

\section{Kewarganegaraan}

Permendiknas No.22 Tahun 2006 bahwa mata pelajaran PPKn bertujuan agar peserta didik memiliki kemampuan sebagai berikut : (a) berpikir secara kritis, rasional dan kreatif dalam menanggapi isu kewarganegaraan, (b) berpartisipasi secara aktif dan bertanggung jawab dan bertindak secara cerdas dalam kegiatan bermasyarakat, berbangsa, bernegara, serta anti korupsi, (c) berkembang secara positif dan demokratis untuk membentuk diri berdasarkan karakterkarakter masyarakat indonesia agar dapat hidup bersama dengan bangsa-bangsa lain, (d) berinteraksi dengan bangsa-bangsa lain dalam peraturan dunia secara langsung atau 
tidak langsung dengan memanfaatkan teknologi informasi dan komunikasi.

Untuk mencapai tujuan tersebut maka seyogyanya pembelajaran PPKn tidak hanya didominasi dengan ceramah yang dilakukan guru namun melibatkan siswa untuk berpartisispasi secara langsung dalam pembelajaran. Hal ini sesuai dengan pendapat Arthur K. Eliis (Samsuri, 2011: 4) bahwa kata kunci dalam pembelajaran PPKn ialah partisipasi. Untuk itu guru dapat membuat rancangan kegiatan yang memunculkan partisipasi siswa dalam belajar sehingga dapat mencapai tujuan PPKn yang telah ditentukan.

\section{Pengertian Hasil Belajar}

Tujuan akhir dilaksanakannya kegiatan pembelajaran yaitu untuk memperoleh hasil belajar. Menurut Oemar Hamalik (2006: 30) hasil belajar diperoleh jika terjadi perubahan tingkah laku, dari tidak tahu menjadi tahu dan dari tidak mengerti menjadi mengerti. Perubahan tersebut dapat diartikan terjadinya peningkatan dan perkembangan lebih baik dari sebelumnya. Sedangkan menurut Agus Suprijono (2009: 5-6) hasil belajar merupakan pola perbuatan, nilai-nilai, pengertian-pengertian, sikap-sikap, apresiasi dan keterampilan. Dengan demikian hasil belajar tidak hanya berdasarkan nilai atau skor yang diperoleh dalam kegiatan pembelajaran.

Hasil belajar menurut pemikiran Gagne (M.Thobroni \& Arik Mustofa, 2013: 22) berupa informasi verbal, keterampilan intelektual, strategi kognitif, keterampilan motorik, dan sikap. Informasi verbal merupakan kemampuan dalam mengungkapkan pengetahuan baik dam bentuk bahasa, lisan maupun tertulis. Jika dikaitkan dalam pembelajaran untuk mengetahui pemahaman materi yang dikuasai siswa dapat dengan memberikan pertanyaan secara lisan maupun pertanyaan tertulis. Namun jika siswa dapat menjawab secara tertulis belum tentu dapat menjawab dengan lisan begitu pula sebaliknya untuk itu perlu diperhatikan perkembangan siswa dalam mengukur informasi verbal.

Sedangkan kemampuan intelektual merupakan kegiatan yang melibatkan aktivitas kognitif seperti menganalisis suatu permasalahan dan kemampuan mengkategorikan. Hampir sama dengan kemampuan intelektual, strategi kognitif lebih menekankan pada konsep dalam memecahkan masalah. Kemudian keterampilan motorik merupakan kemampuan melakukan gerak jasmani. Hasil belajar juga mencakup keterampilan dalam bersikap yang dapat dijadikan acuhan dalam berperilaku.

Menurut Bloom (Agus Suprijono, 2009: 6) hasil belajar mencangkup kemampuan kognitif, afektif dan psikomotorik. Kemampuan kognitif meliputi; pengetahuan, pemahaman, penerapan, analisis, sintesa, evaluasi. Kemampuan afektif meliputi; sikap menerima, memberikan tanggapan, penilaian atau penghargaan, organisasi, karakterisasi. Sedangkan kemampuan psikomotor meliputi; meniru, menerapkan, memantapkan, merangkai dan naturalisasi.

Dari pengertian hasil belajar yang sudah dipaparkan di atas dapat dinyatakan bahwa hasil belajar merupakan perubahan sikap dan tingkah laku manusia yang diperoleh dari kegiatan pembelajaran yang melibatkan aspek kognitif, afektif maupun psikomotorik. Hasil belajar di tandai dengan proses tidak tahu menjadi tahu.

\section{Model Pembelajaran Aktif (Active Learning)}

Model pembelajaran merupakan prosedur dan dijadikan pedoman dalam perancangan pembelajaran. Pendapat tersebut sesuai dengan Soekamto (Trianto, 2010: 22) bahwa model pembelajaran merupakan kerangka konseptual yang menggambarkan prosedur dengan mengorganisasikan pengalaman belajar untuk mencapai tujuan belajar, serta dijadikan pedoman pagi perancang pembelajaran dan guru dalam melakukan kegiatan pembelajaran. Prosedur untuk mengorganisasikan pembelajaran tersebut dirancang secara sistematis.

Model pembelajaran merupakan suatu desain atau rancangan yang menggambarkan proses dan penciptaan situasi lingkungan yang memungkinkan anak 
agar dapat berinteraksi dalam kegiatan pembelajaran, sehingga terjadi perubahan perilaku dalam pembelajaran (Diana Mutiah, 2010: 120). Pembelajaran dirancang agar siswa dapat berinteraksi dalam pembelajaran. Interaksi dapat dilakukan antara siswa dengan guru, siswa dengan siswa lain, atau siswa dengan sumber belajar lainnya. Sedangkan menurut Joyce \& Weil (Rusman, 2010: 133) mengartikan model pembelajaran adalah suatu rencana yang digunakan untuk membentuk kurikulum (rencana pembelajaran dalam jangka panjang) merancang bahan-bahan pembelajaran dan membimbing pembelajaran di kelas atau yang lain.

Dari pengertian model pembelajaran yang sudah dipaparkan di atas dapat disimpulkan bahwa model pembelajaran merupakan pedoman yang digunakan dalam kegiatan pembelajaran. Penggunaan model pembelajaran juga disesuaikan dengan bahan ajar yang akan disampaikan. Dengan menggunakan model pembelajaran prosedur dalam kegiatan pembelajaran akan menjadi sistematis sehingga tujuan pembelajaran tercapai.

\section{Pengertian Model Pembelajaran Aktif (Active Learning)}

Pembelajaran aktif (active learning) merupakan suatu pembelajaran yang menekankan siswa untuk aktif dalam belajar. Kegiatan pembelajaran lebih didominasi pada aktivitas siswa. Kegiatan pembelajaran tidak hanya menekankan pada aktivitas mental namun juga melibatkan aktifitas fisik, sehingga suasana pembelajaran lebih nyaman dan menyenangkan (Hisyam Zaini, 2008 : xiv).

Sedangkan menurut Ari Samadhi (2009: 2) pembelajaran aktif (active learning) merupakan pembelajaran yang memungkinkan siswa turut aktif salam proses pembelajaran, baik dalam bentuk interaksi antar siswa maupun siswa dengan guru.

Dari pendapat yang sudah dijelaskan dapat di ambil kesimpulan bahwa pembelajaran aktif (active learning) merupakan kegiatan belajar yang mengaktifkan siswa, dalam artian siswa terlibat langsung dalam pembelajaran. Pembelajaran aktif membutuhkan interaksi antara guru dengan siswa, serta melibatkan kemampuan siswa baik kognitif, afektif serta prikomotorik, yang diperoleh dari pengalaman belajar.

1. Ciri Pembelajaran Aktif (Active Learning)

Karakteristik pembelajaran aktif menurut Bonwell (Moh.Sholeh Hamid, 2011: 49-50) yaitu dalam pembelajaran siswa tidak hanya pasif mendengakan penjelasan dari guru, namun kegiatan pembelajaran menekankan pada aktivitas belajar siswa. Sehingga siswa aktif dalam pembelajaran. Siswa dituntut untuk berfikir kritis, melakukan analisis dan melakukan evaluasi. Dari hal tersebut diketahui bahwa proses pembelajaran menekankan pada pengembangan keterampilan menganalisis dan mengkritisi persoalan yang berkaitan dengan materi yang dipelajari untuk itu umpan balik dalam pembelajaran sering terjadi. Selain itu dalam kegatan pembelajaran itanamkan sikap-sikap dan nilai karakter kepada siswa yang berkenanan dengan materi yang disampaikan.

Dalam panduan pembelajaran Model Active Learning In School (Uno Hamzah, 2009: 75-76) ciri pembelajaran aktif merupakan pembelajaran yang kegiatannya berpusat pada siswa. Pada pembelajaran aktif siswa di tuntut untuk berfikir kritis, sebab siswa sendiri yang mencari pengetahuannya melalui kegiatan langsung. Untuk itu lingkungan dapat digunakan sebagai media atau sumber belajar siswa. Dengan pembelajaran yang dikaitkan dengan kehidupan nyata dapat mendorong anak untuk berinteraksi dengan lingkungan. Kegiatan guru dalam proses pelaksanaan pembelajaran aktif yaitu memantau siswa dalam belajar. Guru memberikan arahan kepada siswa dalam menemukan pengetahuannya. Pembelajaran aktif menekankan pada aktifitas siswa daripada guru, namun guru tetap mengontrol jalannya kegiatan pembelajaran agar tidak terjadi perbedaan presepsi dalam belajar. Selain itu memberikan umpan balik juga dilakukan oleh guru kepada siswa. Pemberian umpan balik tersebut bertujuan untuk mengapreiasi 
kegiatan yang sudah dilakukan siswa.

Siswa belajar dengan baik dari pengalaman mereka. Pembelajaran aktif salah satunya ditandai dengan siswa belajar dari pengalamannya, selain itu siswa dapat memecahkan masalah yang diperoleh. Siswa belajar dengan cara melakukan, menggunakan panca indra mereka, menjelajahi lingkungan baik benda maupun tempat serta peristiwa-peristiwa yang ada di sekitarnya.

\section{Kelebihan dan Kekurangan Model Pembelajaran Aktif (Active Learning)}

Tiap model pembelajaran yang ada termasuk pembelajaran aktif (active learning) memiliki kelebihan dan kekurangan. Kelebihan dari Active Learning menurut M.Sholeh Hamid (2011: 50) antara lain : a) Interaksi yang dimbul dalam proses pembelajaran akan menimbulkan pengetahuan yang dipelajari hanya dapat diperoleh secara bersama- sama melalui eksplorasi aktif dalam belajar.,b) Siswa harus terlibat aktif dalam proses pembelajaran dan pengajar dapat memberikan penilaian terhadap siswa sehingga terdapat indivisual accountability, c) Agar proses pembelajaran aktif berjalan dengan efektif maka perlu dilakukan kerjasama antar siswa sehingga dapat memupuk keterampilan sosial atau social skills.

Sedangka, kekurangan dari penggunaan pembelajaran aktif (active learning) adalah:a) Membutuhkan waktu yang lebih lama dalam menerapkannya, b) Perlu keterampilan interaksi dan komusikasi pendidik dengan siswa, jika pendidik tidak ada interaksi dan komunikasi yang baik maka tidak terjadi umpan balik dalam pembelajaran, c) Perlu pengkondisian kelas yang bervariasi agar semua siswa aktif dalam pembelajaran,

\section{Model Active Learning Tipe Role Reversal Question}

Pengertian Model Active Learning Tipe Role Reversal Question Model pembelajaran aktif (active learning) bertujuan untuk membuat aktif dalam aktifitas belajar. Menurut Silberman, Mel (2007: 149) menyebutkan ada 101 pembelajaran aktif salah satunya role reversal question. Role reversal question merupakan kegiatan pembelajaran aktif yang menekankan pada aktivitas tanya jawab dengan pertukaran peran. Jika guru bertukar peran menjadi siswa maka guru mengajukan pertanyaan dan siswa mencoba menjawab pertanyaan. Begitupula sebaliknya jika siswa yang mengajukan pertanyaan maka guru yang menjawab.

Dari kegiatan tersebut diketahui bahwa terdapat kegiatan yang dilakukan siswa untuk aktif dalam pembelajaran. Terjadi interaksi antara guru dengan siswa, maupun siswa dengan siwa lain dalam kegiatan tanya jawab. Sehingga aktifitas pembelajaran tidak hanya guru memberikan ceramah mengenai materi pelajaran. Siswa juga latih untuk berani mengajukan pertanyaan serta memberikan pendapat, serta berfikir kritis dalam menjawab pertanyaan.

\section{METODE PENELITIAN Jenis Penelitian}

Penelitian ini merupakan penelitian tindakan kelas (classroom action research). Menurut Suharsimi Arikunto,dkk (2007: 3) penelitian tindakan kelas merupakan suatu pencermatan dari kegiatan pembelajaran berupa tindakan yang sengaja dimunculkan dan terjadi pada sebuah kelas secara bersama. Adapun tujuan penelitian ini adalah untuk meningkatkan hasil belajar PPKn menggunakan model active learning tipe role reversal question kelas III SDN Dondak

Jenis penelitian tindakan kelas yang digunakan dalam penelitian ini adalah kolaboratif, dalam artian peneliti terlibat dalam kegiatan yang digunakan sebagai sumber data penelitian (Sugiono, 2010: 310). Guru bertindak sebagai subyek yang melakukan tindakan sedangkan peneliti sebagai pengamat (observer).

\section{Tempat, Waktu, dan Subyek Penelitian}

Lokasi penelitian yang digunakan dalam penelitian ini yaitu di dalam kelas III SDN Dondak. Sekolah tersebut beralamatkan di Dondak Desa Tanak Awu Kecamatan Pujut Kabupaten Lombok Tengah. Pengambilan data pada penelitian ini dilakukan pada bulan Agustus sampai dengan Oktober 2017, di kelas III SDN 
Dondak dengan jumlah subyek Terdiri dari 10 siswa laki-laki dan 13 siswa perempuan. Sedangkan obyek penelitian ini adalah hasil belajar PPKn dengan Metode role reversal question.

\section{Desain Penelitian}

Menurut Suharsimi Arikunto (2007: 16) penelitian tindakan kelas dilakukan sekurang-kurangnya dalam dua siklus yang berurutan, secara garis besar terdapat empat tahapan yang dilalui yaitu (1) perencanaan, (2) pelaksanaan, pengamatan dan (4) refleksi. Adapun model dan penjelasan untuk masing- masing tahap sebagai berikut;

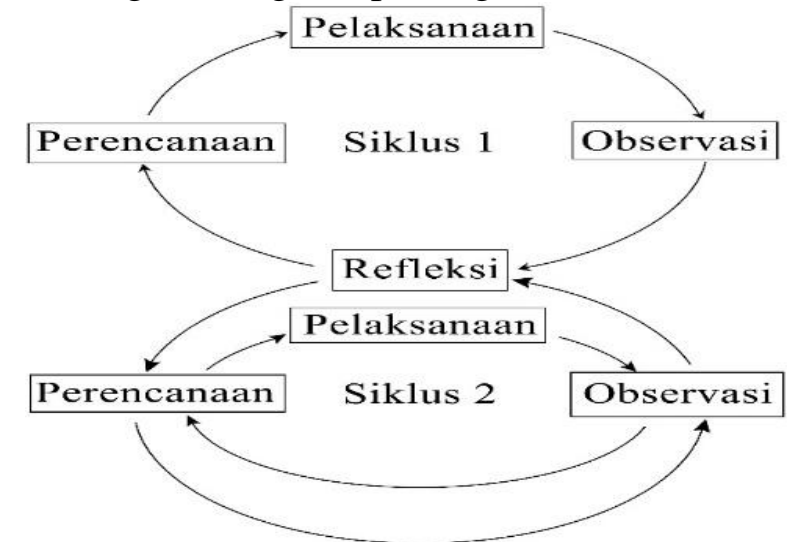

Gambar 2. Desain Penelitian Tindakan

Kelas (Suharsimi, 2007: 16)

\section{Metode Pengumpulan Data}

$$
\text { Metode dan }
$$

instrumen

pengumpulan data yang digunakan dalam penelitian tindakan kelas ini meliputi tes, dan dokumentasi. Adapun metode pengumpulan data dalam penelitian ini adalah dengan menggunakan Tes dan dokumentasi

\section{Teknis Analisis Data}

Dalam penelitian tidakan kelas (PTK) analisis data diarahkan untuk mencari dan menemukan upaya yang dilakukan guru dalam meningkatkan hasil belajar siswa terutama pada mata pelajaran PPKn dengan menuggunakan Metode role reversal question. Dengan demikian analisis data yang digunakan dalam penelitian kelas dapat menggunakan analisis kuantitatif dan kualitatif.

Data kuantitatif diperoleh dari hasil belajar dan aktivitas siswa. Hasil belajar diperoleh melalui tes yang dilakukan pada akhir siklus, sedangkan data aktivitas siswa diperoleh dari pengamatan dalam kegiatan pembelajaran PPKn menggunakan model active learning tipe role reversal question. Rumus statistik yang digunakan untuk mengolah hasil belajar siswa menggunakan statistik sederhana yaitu menggunakan rumus mencari skor rerata kelas. Skor yang diperoleh dengan menjumlahan seluruh skor siswa dan dibagi dengan jumlah siswa. Rumus tersebut sebagai berikut.

$$
\bar{X}=\frac{\sum X}{\sum N}
$$

Keterangan :

$\mathrm{x}=$ skor rata-rata

$\sum \mathrm{x}=$ jumlah skor siswa

$\sum \mathrm{N}=$ jumlah siswa

Untuk menghitung persentase hasil belajar dan aktivitas siswa menggunakan rumus sebagai berikut.

Persentase $(\%)=\frac{\text { Jumlah skor yang diperoleh }}{\text { Jumlah skor maksimal }} \times 100 \%$

Data kualitatif merupakan data yang berupa informasi dalam bentuk kalimat yang tujuannya untuk menggambarkan suatu kegiatan pelajaran. Data kualitatif pada penelitian ini diperoleh dari hasil pengamatan yang di analisis deskriptif sehingga diperoleh data mengenai aktivitas guru dan siswa dalam mengikuti pembelajaran PPKn yang menggunakan metode role reversal question

\section{HASIL DAN PEMBAHASAN \\ Hasil Penelitian \\ Pelaksanaan Tindakan}

Pelaksanaan tindakan siklus I

Hasil belajar diperoleh dari tes yang dilakukan pada setiap akhir siklus. Data yang diperoleh berupa angka mengenai nilai yang diperoleh masing-masing siswa terhadap soal yang dikerjakan setelah diterapkannya model active learning tipe role reversal question dalam proses pembelajaran PPKn . Soal yang diberikan dalam tes ini adalah 10 soal isian,

Berdasarkan hasil belajar siswa diperoleh nilai rata - rata sebesar 69 jumlah siswa yang tuntas belajar sebanyak 13 orang atau dengan persentase ketuntasan sebesar $57 \%$, dan siswa yang tidak tuntas belajar sebanyak 10 orang atau persentase ketidak tuntasan sebesar $43 \%$, ini terjadi karena siswa masih ragu - ragu menggunakan role 
reversal question. untuk melakukan apa yang diperintahkan guru karena masih merasa hal baru. Begitu juga dengan ketuntasan klasikal yang dipersyaratkan sebesar $\geq 80$ juga belum tercapai, maka penelitian ini dilanjutkan ke siklus berikutnya , karena indikator keberhasilan yang di syaratkan belum tercapai sehingga penelitian dilanjutkan ke siklus berikutnya.

\section{Pelaksanaan Penelitian Tindakan Siklus II}

Pelaksanaan tindakna sebagaimana yang tercantum dalam RPP pada siklus II. Berdasarkan hasil analisa dat diketahui hasil belajar siswa diperoleh nilai rata - rata sebesar 80 jumlah siswa yang tuntas belajar sebanyak 21 orang atau dengan persentase ketuntasan sebesar $91 \%$, dan siswa yang tidak tuntas belajar sebanyak 2 orang atau persentase ketidak tuntasan sebesar 0,9\%, ini terjadi karena sudah terbiasa dengan metode role reversal question, untuk melakukan apa yang diperintahkan guru. Begitu juga dengan ketuntasan klasikal yang dipersyaratkan sebesar $\geq 80$ juga sudah tercapai , Sehingga penelitian ini dihentikan sampai pada siklus II. Karena indikator yang dipersyaratkan sudah tercapai.

\section{PEMBAHASAN}

Pelaksanaan penelitian ini dilaksanakan di kelas III SDN Dondak tahun pelajaran 2017 / 2018 dengan subyek penelitian sebanyak 23 orang terdiri dari 13 orang perempuan dan 10 orang laki - laki. Dengan menggunakan Metode role reversal question. Dapat meningkatkan hasil belajar siswa pada mata pelajaran PPKn .

Peningkatan hasil belajar siswa pada siklus I disebabkan oleh Metode role reversal question yang diterapkan oleh guru. Metode role reversal question menekankan pada aktivitas tanya jawab dengan bertukar peran (Silberman Mel, 2007: 149). Pelaksanaan pembelajaran dimodifikasi dengan mempertimbangkan kemampuan dan kebutuhan siswa.

Hasil belajar siswa setelah dilakukan perbaikan tindakan pada siklus II mengalami kenaikan secara signifikan dari pra tindakan, siklus I dan sikus II. Dari siklus I diketahui hasil belajar siswa diperoleh nilai rata - rata sebesar 69 jumlah siswa yang tuntas belajar sebanyak 13 orang atau dengan persentase ketuntasan sebesar $57 \%$, dan siswa yang tidak tuntas belajar sebanyak 10 orang atau persentase ketidak tuntasan sebesar $43 \%$, ini terjadi karena siswa masih ragu - ragu menggunakan role reversal question. untuk melakukan apa yang diperintahkan guru karena masih merasa hal baru. Begitu juga dengan ketuntasan klasikal yang dipersyaratkan sebesar $\geq 80$ juga belum tercapai, maka penelitian ini dilanjutkan ke siklus berikutnya , karena indikator keberhasilan yang di syaratkan belum tercapai.

Pada siklus II, diketahui hasil belajar siswa diperoleh nilai rata - rata sebesar 80 jumlah siswa yang tuntas belajar sebanyak 21 orang atau dengan persentase ketuntasan sebesar $91 \%$, dan siswa yang tidak tuntas belajar sebanyak 2 orang atau persentase ketidak tuntasan sebesar $0,9 \%$, ini terjadi karena sudah terbiasa dengan metode role reversal question, untuk melakukan apa yang diperintahkan guru. Begitu juga dengan ketuntasan klasikal yang dipersyaratkan sebesar $\geq 80$ juga sudah tercapai , Sehingga penelitian ini dihentikan sampai pada siklus II.karena indikator yang dipersyaratkan sudah tercapai.

Jika dibandingkan dari siklus I sampai dengan siklus II terjadi peningkatan hasil belajar yang cukup signifikan dimana pada siklus I diperoleh nilai rata - rata sebesar 69 meningkat pada siklus II sebesar 80 terjadi peningkatan sebesar 11 poin kemudian jumlah siswa yang tuntas pada siklus I sebanyak 13 orang atau persentase ketuntasan sebesar $57 \%$ meningkat pada siklus II menjadi 21 orang siswa yang tuntas belajar atau persentase ketuntasan belajar dengan menggunakan metode role reversal question, sebesar 91\% terjadi peningkatan sebesar 30\%, dan begitujuga dengan ketuntasan klasikal yang dipersyaratkan sebesar $\geq 80$ sudah tercapai maka dengan demikian maka penelitian ini dihentikan sampai pada siklus II

Maka dapat ditarik kesimpulan bahwa penggunaan metode role reversal question, dapat meningkatkan hasil belajar siswa kelas III SDN Dondak Desa Tanak 
Awu Kecamatan Pujut Tahun Pelajaran 2017 / 2018. Peningkatan yang terjadi pada siklus I dan sikus II tidak terlepas dari kegiatan guru yang telah menerapkan Metode role reversal question pada mata pelajaran PPKn - Kegiatan pembelajaran lebih didominasi pada aktivitas siswa dalam memperoleh pengalaman belajar secara langsung dengan bimbingan guru. Hal ini sesuai dengan pendapat R. Ibrahim dan Nana Syaodih (2010: 27) bahwa dalam pembelajaran guru hendaknya merencanakan pengajaran yang menuntut aktivitas siswa. Dengan menerapkan Metode role reversal question siswa tidak hanya aktif dalam pembelajaran, namun juga dibina untuk memiliki sikap cerdas, trampil, berfikir kritis, kreatif, sesuai dengan tujuan dan fungsi PPKn (Permendiknas No.22 Tahun 2006).

\section{PENUTUP}

Berdasarkan hasil penelitian dan pembahasan dapat disimpulkan bahwa pembelajaran PPKn Dengan Metode role reversal question dapat meningkatkan hasil belajar siswa kelas IV SDN Dondak.Langkah-langkah Metode role reversal question meliputi; guru membuat pertanyaan sesuai materi sebelum kegiatan pembelajaran dimulai, menjelaskan kegiatan pembelajaran, membagi siswa dalam beberapa kelompok, menugaskan siswa untuk melakukan diskusi kelompok, menugaskan siswa membuat pertanyaan individu, melakukan tanya jawab dengan bertukar peran dan memberikan umpan balik atas jawaban siswa.

Jika dibandingkan dari siklus I sampai dengan siklus II terjadi peningkatan hasil belajar yang cukup signifikan dimana pada siklus I diperoleh nilai rata - rata sebesar 69 meningkat pada siklus II sebesar 80 terjadi peningkatan sebesar 11 poin kemudian jumlah siswa yang tuntas pada siklus I sebanyak 13 orang atau persentase ketuntasan sebesar $57 \%$ meningkat pada siklus II menjadi 21 orang siswa yang tuntas belajar atau persentase ketuntasan belajar dengan menggunakan metode role reversal question, sebesar $91 \%$ terjadi peningkatan sebesar 30\%, dan begitujuga dengan ketuntasan klasikal yang dipersyaratkan sebesar $\geq 80$ sudah tercapai maka dengan demikian maka penelitian ini dihentikan sampai pada siklus II

Maka ditarik kesimpulan bahwa penggunaan metode role reversal question, dapat meningkatkan hasil belajar siswa kelas III SDN Dondak Desa Tana Awu Kecamatan Pujut Tahun Pelajaran 2017 / 2018

\section{DAFTAR PUSTAKA}

Agus Suprijono. (2009). Cooperative Learning: Teori dan Aplikasi PAIKEM. Yogyakarta : Pustaka Pelajar

A.Ubaedillah \& Abdul Rozak. (2013). Pendidikan Kewarganegaraan (Civic Education): Pancasila, demokrasi, hak asasi manusia dan masyarakat madani. Jakarta: ICCE UIN Syarif Hidayatullah

Ari Samandhi. (2009). Pembelajaran Aktif (Active Learning). Jakarta: Teaching Improvement Worshop Enginering Education Develompment Project.

Baharudin \& Esa Nur Wahyuni. (2009). Teori Belajar dan Pembelajaran. Yogyakarta: Ar-Ruzz Media.

Diana Mutiah. (2010). Psikologi Bermain Anak Usia Dini. Jakarta: Kencana Prenada

Endang Poerwanti dkk. (2008). Asesmen Pembelajaran SD. Jakarta: Dirjen Dikti. Hamruni. (2011). Strategi Pembelajaran. Yogyakarta: Insan Madani.

Hamzah B. Uno dan Nurdin Mohamad. (2012). Belajar dengan Pendekatan

PAILKEM:Pembelajaran Aktif, Inovatif, Lingkungan, Kreatif, Efektif, Menarik. Jakarta: PT.Bumi Aksara.

Moh. Sholeh Hamid. (2011). Metode Edutaiment. Yogyakarta: Diva Press. Redja Mudyahardjo. (2012). Pengantar Pendidikan. Jakarta: Rajawali Pers.

Muhammad Thobroni \& Arik Mustofa. (2013). Belajar \& Pembelajaran: Pengembangan Wacana Dan Praktik Pembelajaran Dalam 
Pembangunan Nasional

Yogyakarta:Ar-Ruzz Media.

Muhibinsyah. (2011). Psikologi Belajar. Jakarta: Rajawali Press.

Nana Sudjana. (2011). Penilaian Hasil Proses Belajar Mengajar. Bandung: PT Remaja Rosda Karya.

Oemar Hamalik. (2006). Proses Belajar Mengajar. Bandung: Bumi Aksara. Permendiknas No.22 Tahun 2006 tentang Standar Isi untuk Satuan Pendidikan

Dasar dan Menengah Dasar. Diakses dari http://bnspindonesia.org/id/?page_id=103 pada tanggal 28 Januari 2017 , jam 16.36 WITA

Redja Mudyahardjo. (2012). Pengantar Pendidikan. Jakarta: Rajawali Pers.

R.Ibrahim dan Nana Syaodih Sukmadinata. (2010). Perencanaan Pengajaran. Jakarta: Rineka Cipta.

Rusman. (2010). Model-Model Pembelajaran: Mengembangkan Profesionalisme Guru. Jakarta : Rajawali Press.

Saiful Bahri Djamarah. (2011).Psikologi Belajar. Jakarta: Rineka Cipta.

Silberman, Mel. (2007). Active Learning: 101 Strategi Pembelajaran Aktif. Penerjemah: Sarjuli. Yogyakarta: Insan Madani.

Sri Esti Wuryani Djiwandono. (2012). Psikologi Pendidikan. Jakarta: Grasindo Garamedia Widiasarana Indonesia.

Sugiyono. (2009). Metode Penelitian Pendidikan Pendekatan Kuantitatif, Kualitatif, dan $R$ \& $D$. Bandung: Alfabeta.

Suyono \& Hariyanto. (2011). Belajar dan Pembelajaran. Bandung: PT.Remaja Rosdakarya.

Undang-Undang Republik Indonesia Nomor 20 tahun 2003 Tentang Sistem Pendidikan Nasional. Yogyakarta: Pustaka Pelajar 